\title{
Lack of correlation between micro fungi species and chemical control method of Atta treated with toxic baits
}

\author{
Marcílio Souza Barbosa ${ }^{1}$ Suzanne Nunes Barbosa ${ }^{2}$ \\ Nilson Satoru Nagamoto ${ }^{3}$ Luiz Carlos Forti ${ }^{3}$ Cícero Almeida ${ }^{2^{*}} \mathrm{G}$
}

${ }^{1}$ Instituto Federal de Alagoas (IFAL), Campus Piranhas, Av Sergipe, s/n, Xingó, Piranhas, AL, Brasil.

${ }^{2}$ Laboratório de Recursos Genéticos, Universidade Federal de Alagoas (UFAL), Campus de Arapiraca, Arapiraca, AL, Brasil. E-mail: cicerocarlos@pesquisador.cnpq.br. "Corresponding author.

${ }^{3}$ Laboratório de Insetos Sociais-Praga, Faculdade de Ciências Agronômicas, Universidade Estadual Paulista (UNESP), Botucatu, SP, Brasil.

\begin{abstract}
Atta sexdens rubropilosa (leaf-cutter ants) has a symbiotic association with a fungus and has a negative interaction with other fungi due to parasitism of the fungus cultivated by ants; also, there are several other fungi with no exact known role occurring in their cultivated fungus garden. In the present study, we use the ITS region (internal transcribed spacer) to identify fungi in colonies treated with toxic baits. Experiments using two toxic baits were carried out: $0.75 \mathrm{~g}$ of sulfluramid [0.3\%] and 0.75g fipronil [0.003\%]. Samples of fungi were collected and cultured in Czapek medium for seven days to allow fungal growth and subsequent identification. Total DNA was isolated from 100-150 mg of mycelium using the CTAB method and using PCR, with the universal primers (ITS4 and ITS5), to amplify the ITS region. Sequencing was performed using the Sanger method. Sequences were subjected to BLAST, allowing the identification of nine different species of the orders Agaricales, Eurotiales, Hypocreales, Pleosporales, Saccharomycetales and Tremellales showing a variation in identity of 96$100 \%$. Using “The Automatic Barcode Gap Discovery” analysis, nine groups were identified, corresponding to species described in NCBI. The $K 2 P$ distances were used to generate a tree using Neighbour-joining, demonstrating that the species were grouped according to phylogenetic groups. We concluded that leaf-cutter ant colonies exhibited a wide variety of fungi and this study suggested that there is no correlation between the species of fungi isolated with the control method used on the ant nest.
\end{abstract}

Key words: ITS, DNA barcoding, leaf-cutter, ants.

Ausência de correlação entre espécies de microfungos e método de controle químico de Atta tratadas com iscas tóxicas

RESUMO: Atta sexdens rubropilosa (cortadeira de folha) possui associação simbiótica com fungos e interação negativa com outros fungos devido a parasitismo do fungo cultivado pelas formigas. Quando colonias da formiga cortadeira de folhas são submetidas ao tratamento com iscas tóxicas, diversas espécies de fungos surgem dentro da colônia, podendo contribuir com a morte ou sobrevivência da colônia. Para entender os relacionamentos ecológicos em colônias de formigas, a identificação de espécie de fungos se torna muito importante e, o uso de DNA barcoding tem sido um método rápido e eficiente para identificação de espécies usando métodos moleculares. No presente trabalho, usamos a região ITS (internal transcribed spacer) para identificar fungos em colonias tratadas com iscas tóxicas. Dois experimentos com iscas tóxicas foram aplicados: $0.75 \mathrm{~g}$ de Fipronil [0.003\%] e $0.75 \mathrm{~g}$ de Sulfluramid [0.3\%]. As amostras, contendo os possíveis fungos, foram coletadas e cultivadas em meio Czaped durante sete dias para o crescimento do fungo e posterior identificação. O DNA total foi isolado de 100-150mg de micélio usando o método CTAB, usado para amplificar a região ITS por PCR empregando primers universais (ITS5 e ITS4). O sequenciamento foi realizado utilizando o método de Sanger. As sequências foram submetidas ao BLAST, permitindo identificar nove diferentes espécies das ordens Agaricales, Eurotiales, Hypocreales, Pleosporales, Saccharomycetales e Tremellales, mostrando variação 96-100\% de identidade. Empregando a análise “The Automatic Barcode Gap Discovery”, identificou-se nove grupos, correspondendo as espécies descritas no NCBI. As distâncias K2P foram usadas para gerar uma árvore usando Neighbour-Joining, apresentando que as espécies foram agrupadas de acordo com as filogenias dos grupos. Conclui-se que as colonias de formigas cortadeira de folhas apresentam grande diversidade de fungos e que DNA barcoding é eficiente para identificação destes.

Palavras-chave: ITS, DNA barcoding, formigas cortadeira, Atta, ecologia.

\section{INTRODUCTION}

Leaf-cutter ants of the Atta genus (Hymenoptera: Formicidae: Attini) are significant pests to agriculture in Latin America and among of them, the Atta sexdens rubropilosa Forel, 1908 species, is one of the most important. These ants live in symbiosis with the fungus Leucoagaricus gongylophorus (Basidiomycota) that they grow for food (SILVA et al., 2003; SILVA-PINHATI et al., 2004; REYNOLDS \& CURRIE 2004). This fungus has been cultivated for millions of years and has been the staple 
diet of $A$. sexdens rubropilosa, however, a negative association with other fungi such as Escovopsis spp. (Ascomycota) also exists, which are specialized parasites to the fungus L. Gongylophorus (CURRIE et al., 1999; REYNOLDS \& CURRIE,2004). There are, also, several less specialized fungi and yeasts in their fungiculture, most of them with uncertain effect, but probably ranging from opportunistic parasite to saprophyticor being symbiont auxiliary (CURRIE et al., 1999; RODRIGUES et al., 2005; MENDES et al., 2012; PAGNOCCA et al. 2012).

The main form of control for ant colonies is based on toxic baits with AIs (active ingredients) such as sulfluramid $\left(\mathrm{C}_{10} \mathrm{H}_{6} \mathrm{~F}_{17} \mathrm{NO}_{2} \mathrm{~S}\right)$ or fipronil $\left(\mathrm{C}_{12} \mathrm{H}_{4} \mathrm{Cl}_{2} \mathrm{~F}_{6} \mathrm{~N}_{4} \mathrm{OS}\right)$; although, the latter is not high efficient for all Atta species (FORTI et al., 2003; ZANETTI et al., 2004). Even for sulfluramid, it was evidenced that not all ants were contaminated (FORTI et al., 2007) and then some ants survive the toxic bait control in the first moment; however, later due to proliferation of other fungi, a decrease in food occurs, causing the death of the colony (FORTI et al., 1998; CURRIE 2001). This evidence suggested that other fungi such as Escovopsis spp., Syncephalastrum racemosum, Trichoderma harzianum and Fusarium oxysporum are important in the control of ant colonies (RODRIGUES et al., 2005).

The correct identification of fungal species is important for understanding the ecological relationships in ant colonies. Morphological descriptions of fungi represent the major source of information for species identification; however, morphological characters alone can be problematic due to the difficulty in identifying fungal structures (revised by BEGEROW et al., 2010). Molecular identification by DNA barcoding has been intensively used and the "internal transcribed spacer" (ITS) region of ribosomal DNA (rDNA) is the official marker for DNA barcoding of fungi (BEGEROW et al., 2010; SEIFERT, 2009; $\mathrm{XU}, 2016)$. Currently, there are over 100,000 fungal ITS sequences generated by Sanger sequencing, deposited in the NCBI and other databases, which can be used for molecular identification of fungi. In this study, we used DNA barcoding to identify fungi in ant colonies treated with toxic baits, associating with chemical control method with.

\section{MATERIAL AND METHODS}

\section{Experimental design}

Colonies of $A$. sexdens rubropilosa were cultured in the laboratory for one year at $23-25^{\circ} \mathrm{C}$ and $50-70 \%$ humidity in a one liter container, coupled with two other $390 \mathrm{ml}$ containers: one serving as foraging arena and another as waste chamber. Ants were fed on leaves of the species Ligustrum spp. and Acalypha spp. and moisture control in the colonies was managed with addition of distilled water or cracked corn. Two experiments were conducted: the first was the control treatment (without toxic baits) and $0.75 \mathrm{~g}$ of sulfluramid $0.3 \%$ (slow activity, promoting death of the colony within seven days) and the second experiment was the control treatment (without toxic baits) and $0.75 \mathrm{~g}$ of fipronil $0.003 \%$ (rapid action, promoting death of the colony within two days). These percentage are based in commercial recommendations and the baits were applied inside of the foraging chamber. Experiments were performed using five colonies with repetitions for each treatment. After seven days (first experiment) and two days (second experiment), samples of small fragments of the fungi were collected (approximately $3 \mathrm{~mm}^{3}$ ), cultured in Czapek medium over seven days to allow for growth of fungus at $25{ }^{\circ} \mathrm{C}$. Specifically, the absence of the L. gongylophorus (symbiotic fungus of $A$. sexdens rubropilosa) in the samples is explained by removal of the fungi for the purpose of identification of the other species.

\section{DNA extraction, amplification and sequencing}

Total DNA was extracted using 100-150mg of mycelium using the CTAB method, described by DOYLE \& DOYLE (1990). Quantification and quality analysis were carried out in 1\% agarose gel. For PCR amplification, a final volume of $50 \mathrm{ml}$ was used containing: 60ng of genomic DNA, 10X enzyme buffer, $1.5 \mathrm{mM} \mathrm{MgCl}_{2}, 0.2 \mathrm{mM}$ dNTP, $1.25 \mathrm{U}$ Taq DNA polymerase and $30 \mathrm{pmol}$ of each primer. Conditions for amplification in the thermocycler were 35 cycles at $94^{\circ} \mathrm{C}$ for $1 \mathrm{~min}, 60^{\circ} \mathrm{C}$ for $1 \mathrm{~min}$ and $72^{\circ} \mathrm{C}$ for $1 \mathrm{~min}$ and a final extension at $72^{\circ} \mathrm{C}$ for $10 \mathrm{~min}$. Universal primers ITS4 and ITS5 (including the ITS1 and ITS2 regions) (WHITE et al. 1990) were used and the sequencing using the Sanger method was carried out in a 3500 genetic analyzer using the DigDye Termination v3.1 Cycle Sequencing Kit.

\section{Data analysis}

Sequences were edited using Mega 5.2 and aligned with Clustal $\mathrm{W}$ and Muscle implemented in the MEGA 5.2. Alignment was done using the default settings and optimized manually when necessary. Initial identification was carried out using BLAST n searches in the NCBI and BOLD databases and then by using the "Automatic Barcode Gap Discovery 
Software"(PUILLANDRE et al., 2012) for identifying DNA barcodes. Interspecific pairwise distances between all species were calculated using Kimura's two-parameter (K2P) model (KIMURA,1980).

\section{RESULTS}

A total of 18 DNA sequences with $524 \mathrm{bp}$ from the ribosomal DNA region (ITS-5.8S-ITS) were obtained for 18 fungi isolates, and the results showed nine species identified: Aspergillus versicolor, Fusarium solani (synonym of F. keratoplasticum), Aspergillus parasiticus, Fusarium oxysporum, Meyerozyma guilliermondii, Trichosporon chiarellii, Penicillium citrinum, Preussia polymorpha and Cyphomyrmex muelleri fungal symbiont. The range in similarities between the sequences with the data from NCBI was $96-100 \%$, indicating a high identity between the sequences (Table 1). Among the sequences identified, Aspergillus versicolor with five individuals predominated, ranging from 96 to $100 \%$ identity between the sequences, followed by F.solani with four individuals, and showing 99 to $100 \%$ sequence identity (Table 1).

Different species were isolated in both experiments. In the experiment with fipronil, three species were identified in the treatments with bait: T. chiarellii, C. muelleriand M. guilliermondii; and fivein the control treatment: F. keratoplasticum, F. solani, M. guilliermondii, $P$. polymorphaand $P$. citrinum. In the experiment with sulfluramid, three species were identified in the treatment with bait: $F$. oxysporum, A. versicolor and A. parasiticus, and in the control treatment the species $A$. versicolor and $F$. keratoplasticum were identified (Table 1).

Identification using Automatic Barcode Gap Discovery (PUILLANDRE et al. 2012) showed nine different groups that corresponded to species identified using BLAST $\mathrm{n}$ searches in the NCBI database, indicating the efficiency of DNA barcoding for species identification. NeighborJoining phylogenetic analysis, generated from K2P distances, showed that species are grouped according to the groups identified using Automatic Barcode Gap Discovery analysis (Figure 1).

\section{DISCUSSION}

The use of DNA barcoding has been widely used to identify species of plants, animals and microorganisms. For fungi, the ribosomal DNA region has been defined as a standard to be used

Table 1 - Identification using DNA barcoding for fungi from ant colonies treated with toxic baits.

\begin{tabular}{|c|c|c|c|c|c|}
\hline Treatments & Isolates & Species & Identify (\%) & GenBank ${ }^{\circ}$ & Groups ${ }^{*}$ \\
\hline Control & F5 & Fusarium solani & 100 & JN235224.1 & 2 \\
\hline Control & $\mathrm{F} 1$ & Fusariumkeratoplasticum & 99 & KC808261.1 & 2 \\
\hline Control & F11 & Meyerozymaguilliermondii & 100 & JQ425356.1 & 5 \\
\hline Control & F10 & Penicilliumcitrinum & 99 & HM486421.1 & 7 \\
\hline Control & F8 & Preussiapolymorpha & 98 & JX076984.1 & 8 \\
\hline Fipronil & F9 & Meyerozymaguilliermondii & 99 & JX455758.1 & 5 \\
\hline Fipronil & F15 & Meyerozymaguilliermondii & 100 & JQ425356.1 & 5 \\
\hline Fipronil & F13 & Trichosporonchiarellii & 96 & GQ338074.1 & 6 \\
\hline Fipronil & F16 & Cyphoтyrmexтиelleri & 99 & JQ617621.1 & 9 \\
\hline Control & F7A & $\begin{array}{l}\text { Aspergillus versicolor } \\
\text {--Second exper }\end{array}$ & 99 & KF733832.1 & 1 \\
\hline Control & F6A & Aspergillus versicolor & 99 & KF733832.1 & 1 \\
\hline Control & F15A & Aspergillus versicolor & 99 & KF017611.1 & 1 \\
\hline Control & F14A & Aspergillus versicolor & 96 & KF017611.1 & 1 \\
\hline Control & F5A & Fusarium keratoplasticum & 100 & KC808261.1 & 2 \\
\hline Control & F12A & Fusarium keratoplasticum & 100 & KC808261.1 & 2 \\
\hline Sulfluramid & F1A & Aspergillus versicolor & 97 & JX122733.1 & 1 \\
\hline Sulfluramid & F13A & Aspergillus parasiticus & 99 & HQ340110.1 & 3 \\
\hline Sulfluramid & $38 \mathrm{c}$ & Fusarium oxysporum & 99 & JX282606.1 & 4 \\
\hline
\end{tabular}

*Number of groups determined in Automatic Barcode Gap Discovery, described by PUILLANDRE et al. 2012. 


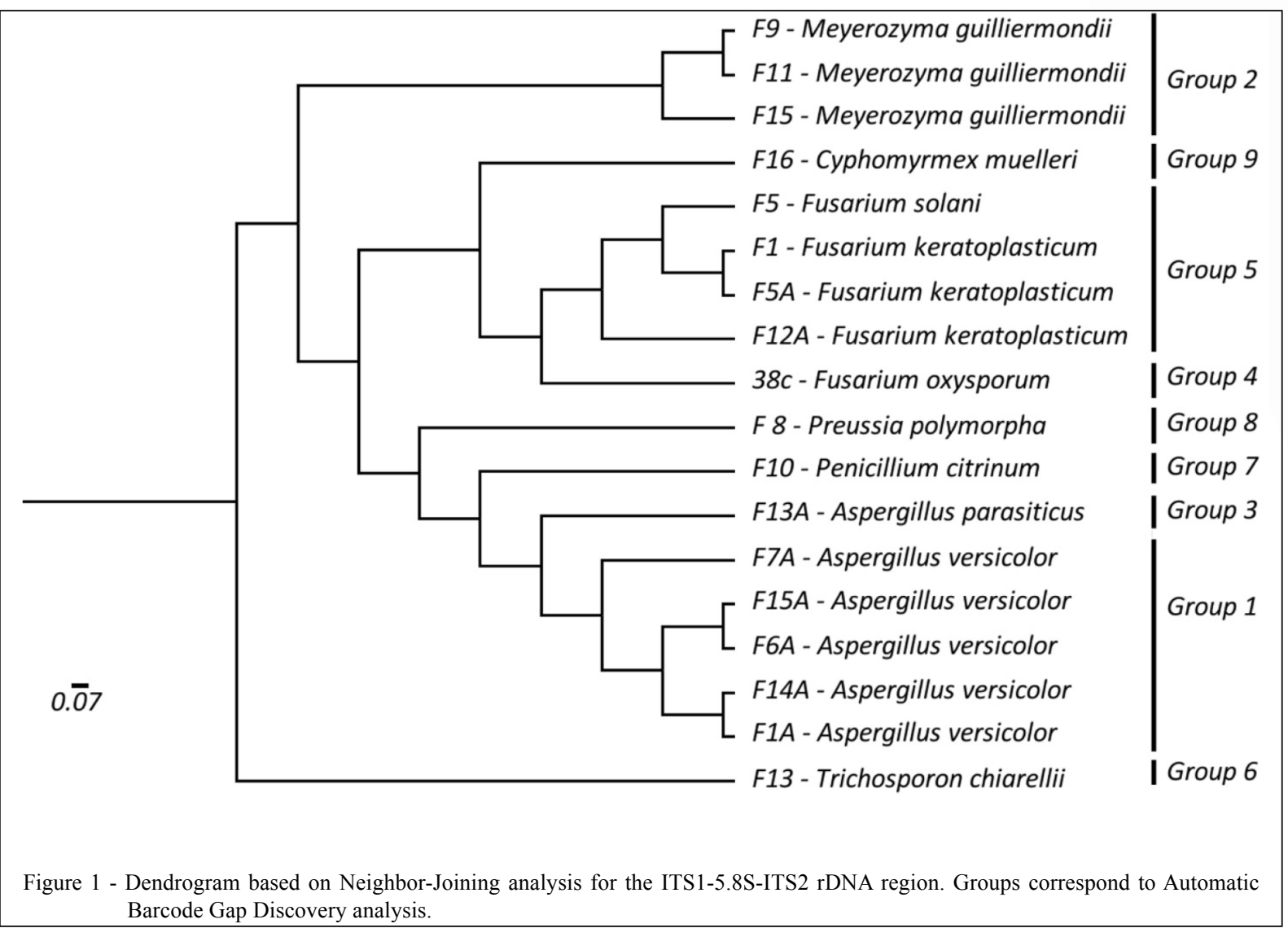

for DNA barcoding (BEGEROW et al., 2010). In this study, the use of these sequences permitted the identification of species of fungi without ambiguity, indicating efficiency for the use of DNA barcoding. It should be emphasized that the use of DNA barcoding technology also permits identification of species at low cost and in less time.

Fungal species are found in ant nests, in a positive or negative association, with symbiotic and parasitic fungal, respectively. Species of Fusarium, Aspergillus, Preussia, Penicillium, Trichosporon and Meyerozyma are some of the fungal genera detected colonizing leaf-ants. RODRIGUES et al. (2005), identified the Fungi $F$. solari, $P$. citrinum and $F$. oxysporum in association with $A$. sexdens rubropilosa. CARLOS et al. (2011) identified $F$. Solari and $P$. citrinum in colonies of $A$. sexdens rubropilosa, after being treated with toxic baits that had sulfluramid in its composition. PAGNOCCA et al. (2010) reported T. chiarellii, in high proportions, in fungal gardens, identified as anamorphic Basidiomycetes fungi. Studies have reported finding filamentous fungi in ant colonies of the genus Atta, and identified as colonies that have suffered some disturbance, either by insecticides, ant removal, or another factor (CURRIE et al., 1999; RODRIGUES et al., 2005; PAGNOCCA et al., 2010; CARLOS et al., 2011). The same behavior was observed in the present study, with a proliferation of fungi occurring after application of insecticide, and the emergence of filamentous fungi and yeast. These fungi can exert a symbiotic role with ants (POULSEN \& CURRIE, 2006) or opportunistic antagonist behavior (PAGNOCCA et al., 2012).

In this context, with the lack of control in the ant nest due to the application of toxic baits, there is a growth of fungi present in the colonies and the data in this study suggested that there is no correlation between the species of fungi isolated with the control method used on the ant nest. The likely explanation is that the microbial flora present in the colonies is related to the plant material deposited in the ant nests or to fungi unintentionally deposited by ants (CURRIE et al., 1999; RODRIGUES et al., 2008). In the present study, opportunistic antagonist filamentous fungi ( $A$. versicolor, $F$. Solaniand $F$. keratoplasticum, A. parasiticus, F. oxysporum, $M$. 
guilliermondii, $P$. citrinumand $P$. polymorpha), yeast (T. chiarellii) and a symbiotic fungus (C. muelleri) reported. The absence of the parasite Escovopsis spp. it not so unexpected result because it is absent in many colonies from some studies (RODRIGUES et al., 2008; 2014).

\section{CONCLUSION}

We concluded that leaf-cutter ants colonies exhibit a wide variety of fungi; however, there is no association with chemical method control.

\section{DECLARATION OF CONFLICT OF} INTEREST

The authors declared no potential conflicts of interest with respect to the research, authorship, and/or publication of this article.

\section{REFERENCES}

BEGEROW, D. et al. Current state and perspectives of fungal DNA barcoding and rapid identification procedures. Applied Microbiology Biotechnology, v.87, p.99-108, 2010. Available from: <https://www.ncbi.nlm.nih.gov/pubmed/20405123>. Accessed: May 18, 2017. doi: 10.1007/s00253-010-2585-4.

CARLOS, A.A. et al. Filamentous fungi found in Atta sexdensrubropilosa colonies after treatment with different toxic bait formulations. Journal Applied Entomology, v.135, p.326331, 2011. Available from: <http://onlinelibrary.wiley.com/ doi/10.1111/j.1439-0418.2010.01551.x/pdf $>$. Accessed: May 18, 2017. doi: 10.1111/j.1439-0418.2010.01551.x.

CURRIE, C.R. et al. The agricultural pathology of ant fungus gardens. Proceedings of the National Academy of Sciences, v.96, p.7998-8002, 1999. Available from: <http://www.pnas.org/ content/96/14/7998.full>. Accessed: May 18, 2017. doi: 10.1073/ pnas.96.14.7998.

CURRIE, C.R. Prevalence and impact of a virulent parasite on a tripartite mutualism. Oecologia, v.128, p.99-106, 2001. Available from: <https://link.springer.com/article/10.1007/s004420100630>. Accessed: May 18, 2017. doi: 10.1007/s004420100630.

DOYLE, J.J.; DOYLE, J.L. Isolation of plant DNA from fresh tissue. Focus, v.12, p.13-15, 1990. Available from: $<$ https://link. springer.com/chapter/10.1007\%2F978-3-642-83962-7_18>. Accessed: May 18, 2017. doi: 10.1007/978-3-642-83962-7_18.

FORTI, L.C. et al (2003). Eficiencia de sulfluramida, fipronil y clorpirifos como sebos enelcontrol de Atta capiguara Gonçalves (Hymenoptera: Formicidae). Pasturas Tropical, v.25, p.28-35, 2003.

FORTI, L.C. et al. Controle de formigas cortadeiras com isca granulada, pp.113-132. In: Berti Filho, E., Mariconi, F.A.M., Fontes, L.R. (eds.). Anais do Simpósio sobre Formigas Cortadeiras dos Países do Mercosul, Piracicaba, Brazil. FEALQ, Piracicaba. 1998.
FORTI, L.C. et al. Dispersal of the delayed action insecticide sulfluramid in colonies of the leaf-cutting ant Atta sexdensrubropilosa (Hymenoptera: Formicidae). Sociobiology, v.50, p.1149-1163, 2007.

KIMURA, M. A simple method for estimating evolutionary rate of base substitutions through comparative studies of nucleotide sequences. Journal Molecular Evolution, v.16, p.111120, 1980. Available from: <https://www.ncbi.nlm.nih.gov/ pubmed/7463489>. Accessed: May 18, 2017.

MENDES, T.D. et al. Generation of nutrients and detoxification: possible roles of yeasts in leaf-cutting ant nests. Insects, v.3, p.228245, 2012. Available from: <https://www.ncbi.nlm.nih.gov/pmc/ articles/PMC4553625/>. Accessed: May 18, 2017. doi: 10.3390/ insects 3010228

PAGNOCCA, F.C. et al. Yeasts isolated from a fungus-growing ant nest, including the description of Trichosporonchiarellii sp. nov., an anamorphic basidiomycetous yeast. International Journal of Systematic and Evolutionary Microbiology, v60, p.1454-1459, 2010. Available from: <https://www.ncbi.nlm.nih. gov/pubmed/19671730>. Accessed: May 18, 2017. doi: 10.1099/ ijs.0.015727-0.

PAGNOCCA, F.C. et al. Specialized fungal parasites and opportunistic fungi in gardens of Attine ants. Psyche, v.2012, 9, 2012. Available from: <https://www.hindawi.com/journals/ psyche/2012/905109/>. Accessed: May 18, 2017. doi: 10.1155/2012/905109.

POULSEN, M.; CURRIE, C.R. Complexity of insect-fungal associations: exploring the influence of microorganisms on attine ant-fungus symbiosis. In: Bourtzis, K., Miller, T.A., (Eds.). Insect Symbiosis, CRC Press, Florida. P.57-77, 2006.

PUILLANDRE, N. et al. ABGD, Automatic Barcode Gap Discovery for primary species delimitation. Molecular Ecology, v.21, p.1864-1877, 2012. Available from: <https://www.ncbi. nlm.nih.gov/pubmed/21883587>. Accessed: May 29, 2017. doi: 10.1111/j.1365-294X.2011.05239.x.

REYNOLDS, H.T.; CURRIE, C.R. Pathogenicity of Escovopsisweberi: the parasite of the attine ant-microbe symbiosis directly consumes the ant-cultivated fungus. Mycologia, v.96, p.955-959, 2004. Available from: <https://www.ncbi.nlm. nih.gov/pubmed/21148916>. Accessed: May 29, 2017. doi: $10.1080 / 15572536.2005 .11832895$

RODRIGUES, A. et al. Variability of non-mutualistic filamentous fungi associated with Atta sexdensrubropilosa nests. Folia microbiology (Praha). v.50, p.421-425, 2005.

RODRIGUES, A., et al. Fungal communities in the garden chamber soils of leaf-cutting ants. Journal of Basic Microbiology, v.54, p.1186-1196, 2014. Available from: <https://www.ncbi.nlm.nih. gov/pubmed/23681670>. Accessed: May 29, 2017. doi:

SEIFERT, K.A. Progress towards DNA barcoding of fungi. Molecular Ecology Resources, .9, p83-89, 2009. Available from: $<$ https://www.ncbi.nlm.nih.gov/pubmed/21564968>. Accessed: May 29, 2017. doi: 10.1111/j.1755-0998.2009.02635.x.

SILVA, A., et al. Survival of Atta sexdens on different food sources. Journal of Insect Physiology, v. 49, p.307-313, 2003 
SILVA-PINHATI, A. C. O. et al. Low variation in ribosomal DNA and internal transcribed spacers of the symbiotic fungi of leaf-cutting ants (Attini: Formicidae). Brazilian Journal of Medical and Biological Research, v.37, p.1463-1472, 2004. Available from: <http://www. scielo.br/scielo.php? script $=$ sci_arttext\&pid $=$ S $0100-$ 879X2004001000004>. Accessed: May 29, 2017. doi: 10.1590/S0100-879X2004001000004.

WHITE, T.J. et al. Amplification and direct sequencing of fungal ribosomal RNA genes for phylogenetics. In: Innis, M.A., Gelfand, D.H., Sninsky, J.J., White, T.J., (Eds.). PCR Protocols:
A Guide to Methods and Applications, Academic Press, New York. pp. 315-322. 1990.

XU, J. Fungal DNA barcoding. Genome 59:913-932, 2016. doi:10.1139/gen-2016-0046

ZANETTI, Ronald et al. Efficiency of granulated baits (sulfluramid $0.3 \%$ ) in the control of Atta sexdens rubropilosa Forel, 1908 (Hymenoptera: Formicidae). Ciênc. Agrotecnologia, v.28, p.878882. 7054. 2004. Available from: <http://www.scielo.br/scielo. php?pid $=$ S1413-70542004000400021\&script $=$ sci abstract\&tlng $=$ pt $>$. Accessed: May 29, 2017. doi: 10.1590/S1413-70542004000400021. 